\title{
Case of extra-pulmonary tuberculosis mycobacterium mimicking a colon cancer
}

\author{
Jordan Powell, ${ }^{1}$ Michael Bath, ${ }^{1,2}$ Heman Joshi, ${ }^{1}$ Michael Machesney ${ }^{1}$
}

${ }^{1}$ Department of Surgery, Whipps Cross University Hospital, London, UK

${ }^{2}$ Centre for Neuroscience, Surgery and Trauma, Queen Mary University of London, London, UK

\section{Correspondence to}

Mr Michael Bath;

michael.bath@doctors.org.uk

Accepted 21 April 2020

\section{DESCRIPTION}

A 66-year-old British woman of Pakistani descent (UK resident since 1970) presented to the colorectal clinic via a 2-week wait referral for unexplained iron deficiency anaemia. She reported a recent unintentional weight loss, however denied any change in bowel habit, per rectal bleeding, or abdominal pain. Her previous medical history included hypertension and type 2 diabetes mellitus, and no previous abdominal surgery.

Following initial consultation, urgent endoscopic and radiological investigations were organised. Computed Tomography (CT) imaging of the chest, abdomen, and pelvis identified a segment of irregular caecal and ascending colon wall thickening suggestive of primary colonic malignancy, with associated mesenteric lymph node involvement (figure 1). Indeterminate subpleural nodules and mediastinal lymph nodes with partial calcification were noted in the chest but deemed of limited relevance after discussion with the radiology team. Colonoscopy noted a malignant-looking stricture, measuring $5 \mathrm{~cm}$, in the ascending colon (figure 2). Biopsies showed focal ulceration with non-necrotising granulomata, but no dysplastic or malignant cells were seen. Gastroscopy revealed only mild gastritis.

Given the compelling evidence from the imaging, the multidisciplinary team decision was to list the patient for an urgent laparoscopic right hemicolectomy with anastomosis for suspected cancer. The procedure was performed successfully and the specimen excised. Intraoperatively, there

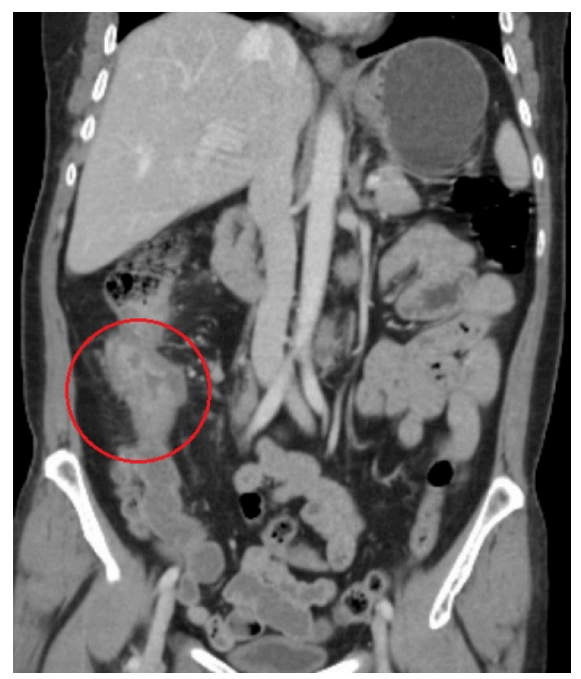

Figure 1 Coronal slice of CT scan of the patient's abdomen highlighting the abdominal mass in the ascending colon.

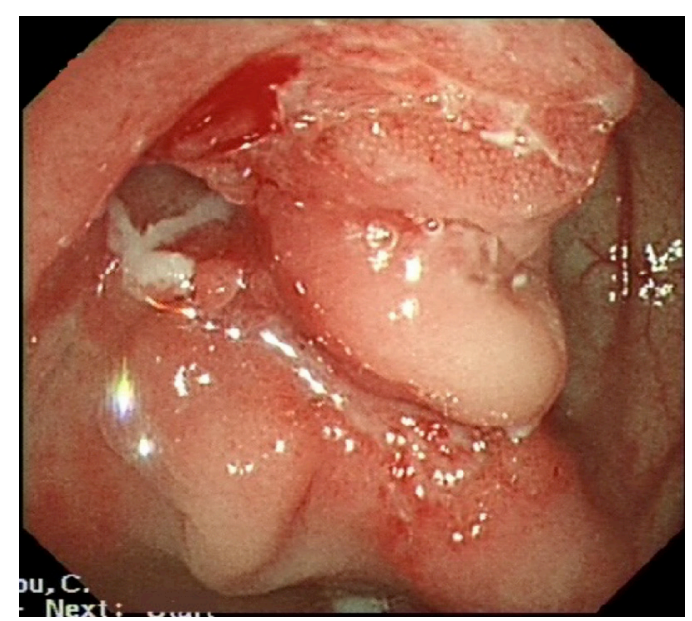

Figure 2 Colonoscopy image showing the malignant looking lesion in the ascending colon.

were extensive adhesions noted throughout the abdomen, involving the large and small bowel, the liver and anterior abdominal wall. The postoperative period was unremarkable and the patient was discharged home 7 days later.

The histopathology report of the resection noted extensive necrotising granulomas, including the presence of Langhans giant cells, involving the bowel wall and lymph nodes (figure 3 ). This was reported as highly suggestive of tuberculosis (TB) mycobacterium, with no evidence of dysplasia or malignancy. While supplementary testing failed to identify any acid-fast bacilli on Ziehl-Neelsen staining, nor any pathogens on culture, based on the histology, intestinal TB was deemed the most likely diagnosis.

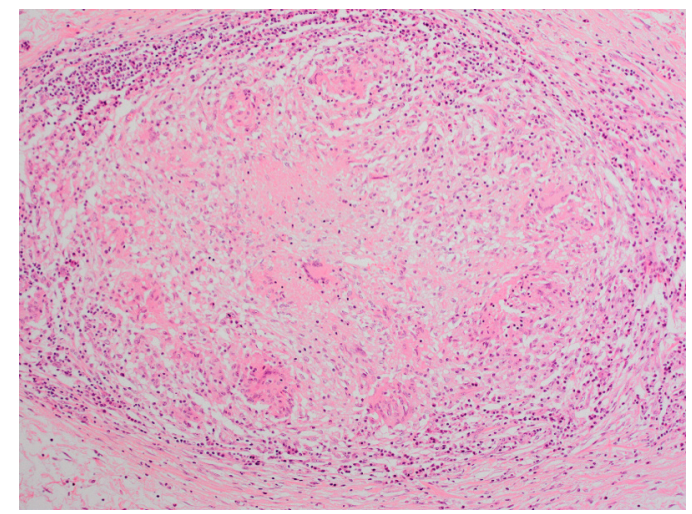

Figure 3 Histology of the specimen, demonstrating the necrotising granulomas identified, including the presence of Langhans giant cells. 
Intestinal TB is a rare diagnosis, especially in high-income countries, and isolated colon bacterium account for less than 3\% of all presentations. ${ }^{1}$ Histological identification is highly variable; only around $40 \%$ of cases specifically identify granulomas, with positive staining of the bacilli even less prevalent. ${ }^{2}$ Clinical features of intestinal TB include abdominal pain, weight loss, fevers or night sweats and change in bowel habit. ${ }^{13}$ Colonoscopy findings are often equally variable, most commonly identifying ulcerated lesions with irregular mucosal surroundings; ${ }^{1-3}$ however, lesions can result in luminal narrowing, ${ }^{2}$ deformed bowel segments ${ }^{1}$ or even polypoidal lesions, meaning a significant portion of cases convincingly mimic carcinomas. ${ }^{3}$

The patient was referred to the specialist TB clinic, whereby further exploration of the relevant history revealed no contact

\section{Learning points}

- Intestinal tuberculosis can mimic the presence of bowel cancer clinically, radiologically and endoscopically.

- When histologically confirmed, long-course anti-tuberculosis therapy is a reliable treatment for intestinal tuberculosis. with TB. The pulmonary nodules were deemed not suitable for biopsy. In the absence of an alternative clinical diagnosis, a 6-month course of anti-TB therapy was initiated, consisting of rifampicin, isoniazid, pyrazinamide, ethambutol, and pyridoxine. Four months post-operatively, treatment is ongoing and the patient is clinically well.

\section{Twitter Michael Bath @MikeFBath}

Contributors JP, MB and $\mathrm{HJ}$ all contributed to the conception, drafting and revision of the article. MM contributed to conception and critical revision of the article. All authors approved the final version to be published.

Funding The authors have not declared a specific grant for this research from any funding agency in the public, commercial or not-for-profit sectors.

Competing interests None declared.

Patient consent for publication Obtained.

Provenance and peer review Not commissioned; externally peer reviewed.

\section{REFERENCES}

1 Kumar A, Patodia M, Pandove P, et al. Colonic tuberculosis masquerading as colon cancer. J Surg Case Rep 2012;2012:10.

2 Yu S-M, Park J-H, Kim M-D, et al. A case of sigmoid colon tuberculosis mimicking colon cancer. J Korean Soc Coloproctol 2012;28:275-7.

3 Debi U, Ravisankar V, Prasad KK, et al. Abdominal tuberculosis of the gastrointestinal tract: revisited. World J Gastroenterol 2014;20:14831-40.

Copyright 2020 BMJ Publishing Group. All rights reserved. For permission to reuse any of this content visit https://www.bmj.com/company/products-services/rights-and-licensing/permissions/ BMJ Case Report Fellows may re-use this article for personal use and teaching without any further permission.

Become a Fellow of BMJ Case Reports today and you can:

- Submit as many cases as you like

- Enjoy fast sympathetic peer review and rapid publication of accepted articles

- Access all the published articles

Re-use any of the published material for personal use and teaching without further permission

Customer Service

If you have any further queries about your subscription, please contact our customer services team on +44 (0) 2071111105 or via email at support@bmj.com.

Visit casereports.bmj.com for more articles like this and to become a Fellow 